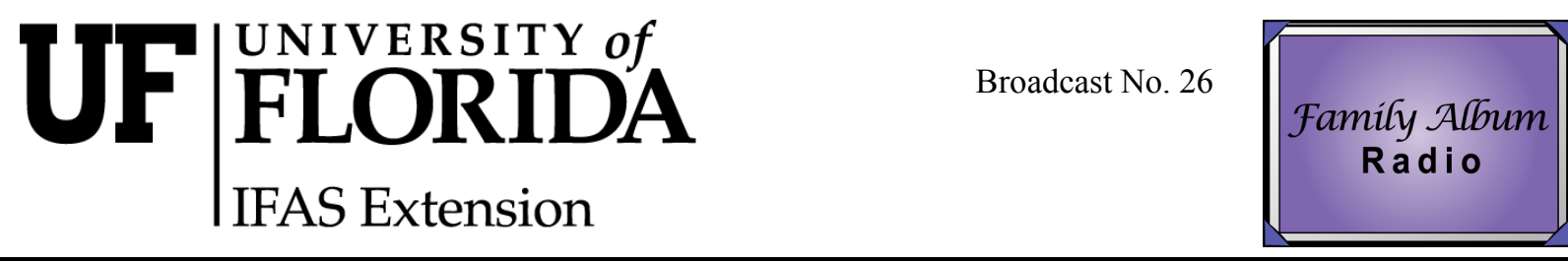

Transcribed from the Family Album Radio Program, a co-production of University of Florida IFAS Extension, the Department of Family, Youth and Community Sciences and of WUFT-FM. If you'd like to learn more, please visit our website at familyalbumradio.org

Listening, learning and living together, it's the science of life.

\section{Nutrition: Boring Food}

\section{Donna Davis and Linda Bobroff ${ }^{2}$}

The diet industry represents a multi-billion dollar industry today. New books and diet programs appear almost every week with offers to help us FINALLY figure out how to eat right and stay in shape. While these programs are typically targeted to adults, the adults who are dealing with their own nutrition issues are also raising the next generation... often with the same rules they learned as kids or imposing the new rules they are trying to follow as adults. In many cases, neither of these are appropriate.

For example, according to Ellyn Satter, low-fat food is neither nutritionally appropriate nor appealing to toddlers (much less adults!). Likewise, for all the Atkins followers out there, starches are not only good for children, but appealing. Satter recommends always having bread and a second starchy food on the table.

Another important shift in philosophy is over control. For all of you raised by the "yours is not to question why, yours is but to do or die" parenting style, consider this. Satter says you're too controlling if you make your child stay at the table to eat her vegetables; make your child clean her plate or eat everything else before she can have dessert; or if you make your child get by on only three meals a day. However, she says you aren't providing your child enough structure and limits if you give your child a snack whenever

1. This document is FAR7000, one of a series of the Family, Youth and Community Sciences Department, Florida Cooperative Extension Service, Institute of Food and Agricultural Sciences, University of Florida. Original publication date May 30, 2006. Some scientific language from the original script has been modified to better serve the listener. The script published here represents the actual broadcast as heard on Family Album Radio. Visit the EDIS Web Site at http://edis.ifas.ufl.edu

2. Donna Davis, Senior Producer, Family Album Radio and Linda Bobroff, Professor, Foods and Nutrition, Department of Family, Youth and Community Sciences, Cooperative Extension Service, Institute of Food and Agricultural Sciences, University of Florida, Gainesville, FL 32611.

The Institute of Food and Agricultural Sciences (IFAS) is an Equal Employment Opportunity - Affirmative Action Employer authorized to provide research, educational information and other services only to individuals and institutions that function without regard to race, creed, color, religion, age, disability, sex, sexual orientation, marital status, national origin, political opinions or affiliations. For information on obtaining other extension publications, contact your county Cooperative Extension Service office. Florida Cooperative Extension Service / Institute of Food and Agricultural Sciences / University of Florida / Larry R. Arrington, Dean. 
she wants one; let your child behave badly at the table; short-order cook for her; or let your child have juice or milk whenever she wants it. (Like most of parenting... there's plenty of give and take.)

More information, please visit our website at www.familyalbumradio.org

\section{To listen to the radio broadcast:}

http://radiosource.net/radio_stories/boring.wav

http://radiosource.net/radio_stories/boring.mp3

\section{Reference}

Satter, Ellen. "Child of Mine". Bull Publishing, 2000 Boulder, CO. 